\title{
SOSIALISASI MANFAAT TEMPE DAN PELATIHAN PENGOLAHAN TEMPE MENJADI TEPUNG SEBAGAI ALTERNATIF PENGGANTI TEPUNG TERIGU
}

\author{
Oktavina Permatasari ${ }^{1 *}$, Zuhria Ismawanti ${ }^{2}$, Arwin Muhlishoh ${ }^{3}$, \\ Inayatush Sholihah ${ }^{4}$ \\ ${ }^{1-4}$ Universitas Kusuma Husada Surakarta \\ Email Korespondensi: tataoktavinaa@gmail.com
}

Disubmit: 21 Juli 2021

Diterima: 09 Agustus 2021

Diterbitkan: 04 Februari 2022

DOI: https://doi.org/10.33024/jkpm.v5i2.4704

\begin{abstract}
ABSTRAK
Perkembangan produk makanan semakin pesat dan beragam di Indonesia dan memberikan kontribusi besar terhadap asupan zat gizi seseorang. Berdasarkan tingginya konsumsi tepung terigu pada masyarakat, mendorong untuk dapat menggunakan bahan pangan lokal sebagai pengganti tepung terigu. Salah satu yang berpotensi sebagai bahan baku tepung adalah tempe. Kegiatan sosialisasi dan pelatihan pembuatan tepung tempe ini dilaksanakan secara daring (online) dua arah dengan menggunakan aplikasi zoom, video, dan yotube sesuai arahan Puskesmas karena kondisi pandemi Covid-19 di Wilayah Dusun Wonorejo Gondangrejo Kabupaten Karanganyar. Berdasarkan dari hasil kegiatan sosialisasi dan pelatihan pada peserta, terdapat peningkatan pengetahuan dan kemampuan peserta dalam pemahaman manfaat tempe yang terlihat dari hasil kuesioner sebelum dan sesudah mengikuti pelatihan. Berdasarkan hasil pretest Sebanyak 25 peserta memiliki pengetahuan kurang atau nilai dibawah 70 dan 10 peserta memiliki pengetahuan baik atau nilai diatas 70 , sedangkan hasil postest diperoleh peningkatan pengetahuan dari peserta dengan hasil rerata nilai 81 , dengan 7 peserta memiliki pengetahuan kurang dan 28 peserta memiliki pengetahuan baik. Selain itu dari hasil evaluasi wawancara pada bulan berikutnya terdapat peningkatan keterampilan dan keahlian peserta yang yang sudah mengaplikasikan membuat tepung tempe secara mandiri dan digunakan sebagai bahan baku dproduk makanan sehari-hari.
\end{abstract}

Kata Kunci : Peningkatan pengetahuan, pelatihan tempe, tepung tempe, pembuatan tepung tempe

\begin{abstract}
The development of food products is increasingly rapid and diverse in Indonesia and contributes greatly to a person's nutrient intake. Based on the high consumption of wheat flour in the community, it is encouraging to be able to use local food ingredients as a substitute for wheat flour. One of the potential raw materials for flour is tempeh. The socialization and training in making tempeh flour was carried out online in two directions using the zoom, video, and youtube applications according to the direction of the Health Center due to the Covid-19 pandemic condition in the Wonorejo Gondangrejo, Kabupaten Karanganyar. Based on the results of the socialization and training activities for participants, there was an increase in participants' knowledge and ability in
\end{abstract}


understanding the benefits of tempeh as seen from the results of the question before and after participating in the training. Based on the results of the pretest, 25 participants had poor knowledge or scores below 70 and 10 participants had good knowledge or scores above 70, while the posttest results obtained an increase in knowledge from participants with an average score of 81 , with 7 participants having poor knowledge and 28 participants having good knowledge. From the results of the interview evaluation in the following month, there was an increase in the skills and expertise of participants who had applied to make tempeh flour independently and used it as a raw material for daily food products.

Keywords : Health Improvement, tempeh, training on tempeh, tempeh flour

\section{PENDAHULUAN}

Perkembangan produk makanan di Indonesia semakin pesat dan beragam yang memberikan kontribusi terhadap asupan zat gizi seseorang. Makanan yang dikonsumsi menjadi perhatian penting di masyarakat karena terdapat beberapa produk makanan yang tidak higienis, tidak mengandung nilai gizi sehingga berisiko terhadap permasalahan kesehatan (Purba, 2018). Salah satu sumber bahan makanan yang banyak dikonsumsi oleh masyarakat Indonesia adalah tempe. Tempe merupakan salah satu makanan tradisional Indonesia yang diolah dengan proses fermentasi yang mengandung nilai gizi tinggi terutama protein (Elisabeth, Dian, dkk., tanpa tahun). Tempe masih dianggap sebagai makanan yang hanya dikonsumsi oleh masyarakat lapisan menengah kebawah, karena harga yang relatif murah. Tempe memiliki kandungan zat gizi yang dibutuhkan tubuh antara lain protein, serat, dan vitamin sehingga digunakan sebagai makanan alternatif yang berfungsi ganda yaitu sebagai sumber gizi bagi tubuh dan sebagai bahan makanan kesehatan.

Konsumsi mayoritas masyarakat Indonesia akan bahan pangan dengan bahan dasar tepung terigu masih sangat besar. Tepung terigu menjadi bahan makanan pokok setelah beras. Indonesia merupakan negara pengimpor tepung terigu / gandum terbesar kedua didunia dengan volume impor diatas 5 juta per ton per tahun (Pradeksa, dkk, 2014). Berdasarkan dari data Badan Pusat Statistika (BPS), volume impor komoditas gandum pada periode semester pertama mengalami kenaikan $4 \%$ dibanding pada tahun sebelumnya.

Berdasarkan tingginya konsumsi tepung terigu pada masyarakat Indonesia, mendorong untuk membuat alternatif tepung sebagai alternatif pengganti tepung terigu dengan bahan lokal. Salah satu yang berpotensi digunakan sebagai bahan baku tepung adalah tempe. Berdasarkan dari hasil penelitian Oktavia, Andi, 2012 tentang Studi Pembuatan Tepung Formula Tempe masih memiliki nilai gizi yang dapat dijadikan alternatif bahan baku pembuatan produk makanan.

Sebagian besar tempe diolah langsung menjadi lauk pada makanan saja, dengan merubah karakteristik fisik tempe menjadi tepung dapat membuat masa simpan tempe lebih lama serta dapat digunakan sebagai bahan utama pengganti tepung terigu pada produk-produk pangan yang pengolahannya menggunakan tepung terigu. Tempe memiliki rasa dan tekstur yang menarik, daya cerna yang sangat tinggi, serta memiliki efek positif terhadap kesehatan seperti mengurangi risiko penyakit jantung, stroke, osteoporosis, kanker, kelainan pencernaan, dan gejala-gejala menopause (Koeryaman \& Ermiati, 2018). Selain itu, tempe juga memiliki nutrisi dan substansi aktif 
seperti protein, nitrogen terlarut, asam amino, dan asam lemak bebas, isoflavon, serta vitamin $B_{12}$ (Harahap, Lubis \& Kaban, 2018)

Dusun Wonorejo merupakan salah satu kecamatan yang terletak di Gondangrejo Kabupaten Karanganyar. Berdasarkan dari hasil wawancara pada salah satu Kader PKK di Wilayah Gondangrejo, masih terdapat masyarakat yang kehilangan pekerjaan dan atau penghasilan ekonomi yang menurun dikarenakan kondisi pandemi ini yang berdampak pada pola konsumsi sehari-hari. Berdasarkan hal tersebut, penulis tertarik untuk memberikan sosialisasi manfaat tempe dan memberikan pelatihan kepada kelompok PKK di Wilayah Gondangrejo Kabupaten Karanganyar tentang manfaat tempe serta pengolahan tempe menjadi tepung sebagai alternatif pengganti tepung terigu. Pelatihan merupakan salah satu kegiatan dimana membantu peserta dalam memperbaiki prestasi dalam kegiatannya terutama mengenai pengertian dan keterampilan. Terlaksananya kegiatan pelatihan ini diharapkan dapat memberikan keahlian atau kemampuan baru kepada kelompok PKK di Wilayah Gondangrejo tentang manfaat tepung tempe bagi kesehatan dan dapat digunakan sebagai alternatif pengganti tepung terigu.

\section{MASALAH}

Kegiatan pengabdian kepada masyarakat ini dilaksanakan di wilayah Dusun Wonorejo Gondangrejo Kabupaten Karanganyar. Dimana berdasarkan hasil wawancara pendahuluan terhadap salah satu kader PKK banyak terdapat warga yang kehilangan pekerjaan pada kondisi pandemi yang berpengaruh terhadap pola asupan sehari-hari sehingga dikhawatirkan dapat mempengaruhi kesehatan. Selain itu, wilayah sasaran juga belum pernah dilakukan kegiatan pengenalan tempe dan kegiatan pelatihan pengolahan tempe menjadi tepung.

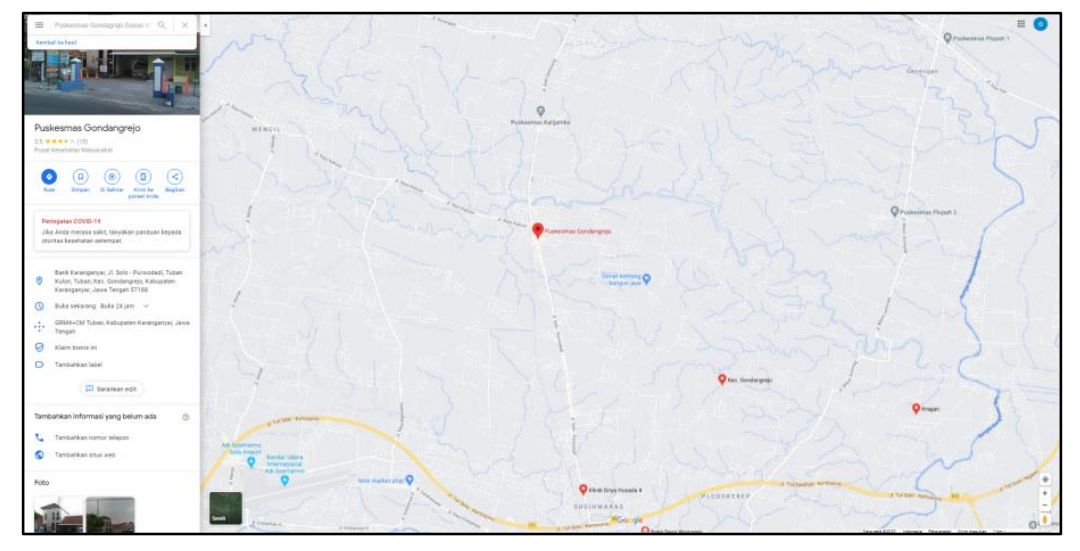

Gambar 1. Peta Lokasi Kegiatan Pengabdian Kepada Mayarakat

\section{METODE}

Kegiatan pengabdian masyarakat ini dilaksanakan di wilayah kerja Puskesmas Gondangrejo Kabupaten Karanganyar pada bulan September 2020 sampai Agustus 2021 yang dilaksanakan bersama dengan mahasiswa Program Studi Gizi Program Sarjana Fakultas Ilmu Kesehatan Universitas Kusuma Husada Surakarta. Pelaksanaan pengabdian kepada masyarakat adalah secara daring atau online dengan yang berdasarkan arahan dari Puskesmas 
Gondangrejo dikarenakan masih dalam kondisi pandemi Covid-19 sehingga tidak memungkinkan dilakukan tatap muka secara langsung. Metode yang digunakan yaitu ceramah menggunakan slide power point, video animasi pembuatan tepung tempe, diskusi dan tanya jawab, pemberian booklet, serta pengisian e-kuesioner. Pelaksanaan kegiatan ini menggunakan media zoom dan youtube yang sebelumnya telah diberikan arahan oleh pengabdi. Kegiatan pengabdian kepada masyarakat ini dimulai dari pendekatan dengan kelompok sasaran, persiapan alat dan materi, pelaksanaan kegiatan, dan evaluasi dengan menggunakan form yang diisi oleh peserta.

\section{HASIL DAN PEMBAHASAN}

Tempe merupakan satu pangan fungsional yang memiliki nilai gizi yang tinggi terutama kandungan protein yang dibutuhkan oleh tubuh. Tempe terbuat dari kacang kedelai yang difermentasi dengan kapang dan diinkubasi sampai diperoleh tekstur tempe. Tahapan pembuatan yang mudah dengan bahan baku yang mudah diperoleh sehingga membuat harga tempe relatif murah. Pada masa pandemi covid-19, banyak masyarakat yang kehilangan pekerjaan dan atau penghasilan menurun yang dapat mempengaruhi pola makan dan asupan zat gizi baik individu maupun dalam keluarga. Berdasarkan dari hal tersebut, perlunya peningkatan pengetahuan tentang tempe dan keterampilan pembuatan tepung tempe yang dapat digunakan sebagai pengganti tepung terigu dalam pembuatan produk makanan dengan komposisi zat gizi yang lebih tinggi. Sehingga diharapkan kebutuhan zat gizi dalam tubuh dapat terpenuhi.

Kegiatan pengabdian kepada masyarakat yang dilakukan adalah sosialisasi manfaat tempe dan pelatihan pengolahan tempe menjadi tepung sebagai alternatif pengganti tepung terigu yang dilaksakanan di Dusun Wonorejo Kecamatan Gondangrejo Kabupaten Karanganyar. Peserta yang mengikuti kegiatan pengabdian masyarakat berjumlah 35 orang wanita dengan sebagian besar berusia 30 - 40 tahun dengan $60 \%$ adalah ibu rumah tangga. Partisipasi dan kesungguhan peserta dalam mengikuti sosialisasi dan pelatihan pembuatan tepung tempe dapat dikatakan baik yang terlihat dari keaktifan peserta selama kegiatan berlangsung dan peningkatan hasil rerata nilai pretest dan post-test.

Pelaksanaan kegiatan pengabdian masyarakat ini diawali dengan pemaparan mengenai tempe, kandungan gizi yang terdapat pada tempe serta manfaat bagi kesehatan dalam bentuk slide yang kemudian dilanjutkan dengan sesi diskusi dimana peserta dapat menanyakan yang belum dipahami. Selain pemaparan, kegiatan pelatihan pembuatan tempe juga dengan media video animasi dimana peserta dapat memiliki gambaran secara langsung bagaimana membuat tepung tempe yang dapat digunakan sebagai alternatif pengganti tepung terigu. Selain video animasi, peserta juga diberikan booklet yang bertujuan untuk memudahkan peserta ketika kegiatan sosialisasi dan pelatihan sudah berakhir. Media booklet sebagai pendidikan gizi dapat membantu peserta untuk lebih mengerti dan memahami informasi yang disampaikan (Irawati, 2019).

Dalam penyampaian pendidikan kesehatan dipengaruhi oleh metode dan media yang digunakan. Menurut Meliono (2007), pengetahuan dipengaruhi oleh beberpa faktor yaitu pendidikan, media, dan keterpaparan informasi. Kegiatan pengabdian masyarakat ini dilaksanakan secara daring atau online 
dengan metode pemaparan dengan ceramah dengan slide presentasi, diskusi, penayangan video animasi, dan pemberian booklet kepada seluruh peserta.

Metode ceramah dilakukan sebagai bentuk pengantar dan pemaparan mengenai definisi tempe, kandungan gizi tempe, manfaat tempe bagi kesehatan kemudian dilanjutkan dengan diskusi dimana pada sesi ini peserta antusias dalam mengikuti karena adanya interaksi dua arah antara pemateri dengan peserta selama kegiatan berlangsung. Selain itu kegiatan pelatihan pembuatan tepung tempe menggunakan media video animasi yang ditayangkan dalam zoom dan youtube dengan laman https://www.youtube.com/watch?v=WjVd9PMKvN4 agar peserta memiliki gambaran langsung tahapan dalam pembuatan tepung tempe dikarenakan tidak dapat dilakukan secara langsung sehingga menggunakan video adalah metode yang tepat dalam penyampaian demonstrasi pembuatan tepung tempe.

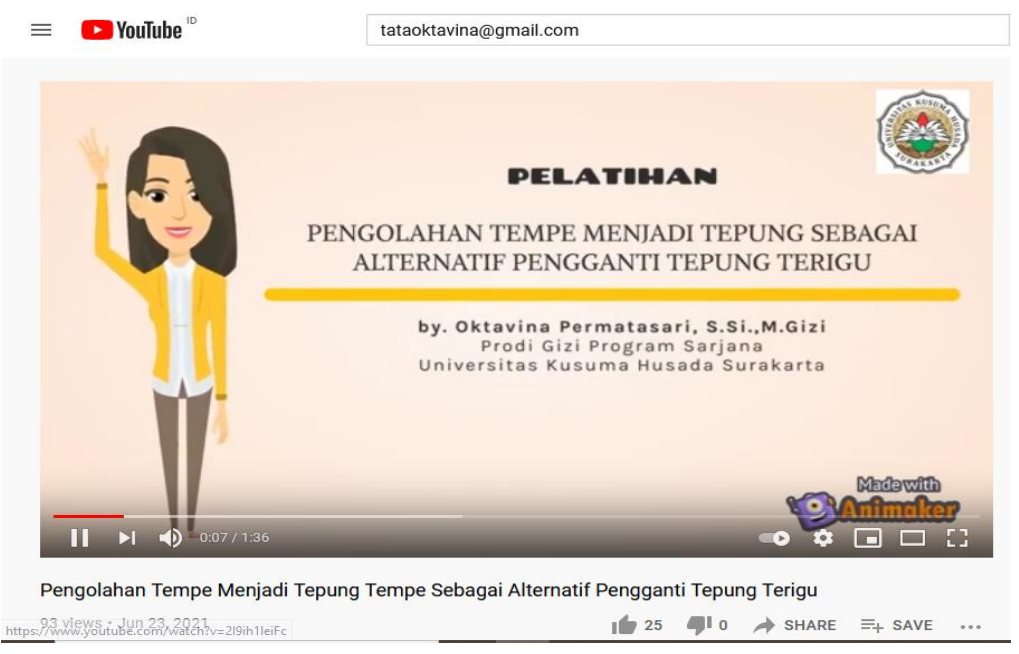

Gambar 2. Video Animasi Pelatihan Pembuatan Tepung Tempe

Pendidikan kesehatan metode dengan media video mampu meningkatkan pengetahuan yang semula peserta mempunyai pengetahuan yang kurang, setelah pemaparan dilakukan peserta mempunyai pengetahuan yang baik. Hal tersebut sejalan dengan hasil penelitian yang dilakukan oleh Santi et.al (2014), menunjukkan bawa ada perbedaan perilaku responden sebelum diberikan pendidikan kesehatan menggunakan media audiovisual dengan setelah diberikan pendidikan kesehatan menggunakan media audiovisual. Video animasi merupakan bagian dari audiovisual yang melibatkan indera pendengaran dan indera penglihatan sehingga minat, perhatian, dan konsentrasi remaja hingga dewasa menjadi lebih terfokus.

Tahapan terakhir dalam kegiatan pengabdian masyarakat ini adalah dengan pemberian booklet kepada seluruh peserta untuk memudahkan pemahaman peserta dirumah setelah kegiatan sosialisasi dan pelatihan berakhir. Hal ini sejalan dengan hasil penelitian Rizqiea, 2019 bahwa pemberian booklet mampu meningkatkan pengetahuan dan keterampilan Ibu dalam memberikan ASI ekslusif. Selain itu sejalan dengan penelitian Safitri, 2018 dimana pemberian booklet memberikan pengaruh terhadap peningkatan pengetahuan, sikap, dan dukungan suami terhadap ASI ekslusif.

Dalam kegiatan ini, peserta harus mengisi e-kuesioner yang diberikan sebelum kegiatan dimulai dan setelah kegiatan selesai sebagai monitoring dan evaluasi yang bertujuan untuk mengetahui perubahan pengetahuan 
peserta dalam mengikuti kegiatan sosialisasi. Berdasarkan dari hasil evaluasi yang dilakukan diperoleh hasil rerata pretest 66 yang menunjukkan bahwa peserta kurang memahami mengenai manfaat tempe dan pengolahan tempe menjadi tepung. Sebanyak 25 peserta memiliki pengetahuan kurang atau nilai dibawah 70 dan 10 peserta memiliki pengetahuan baik atau nilai diatas 70. Hasil postest diperoleh peningkatan pengetahuan dari peserta dengan hasil rerata nilai 81 , dengan 7 peserta memiliki pengetahuan kurang dan 28 peserta memiliki pengetahuan baik. Hasil pengetahuan peserta sebelum dan sesudah sosialisasi dan pelatihan dapat dilihat pada Gambar 3.

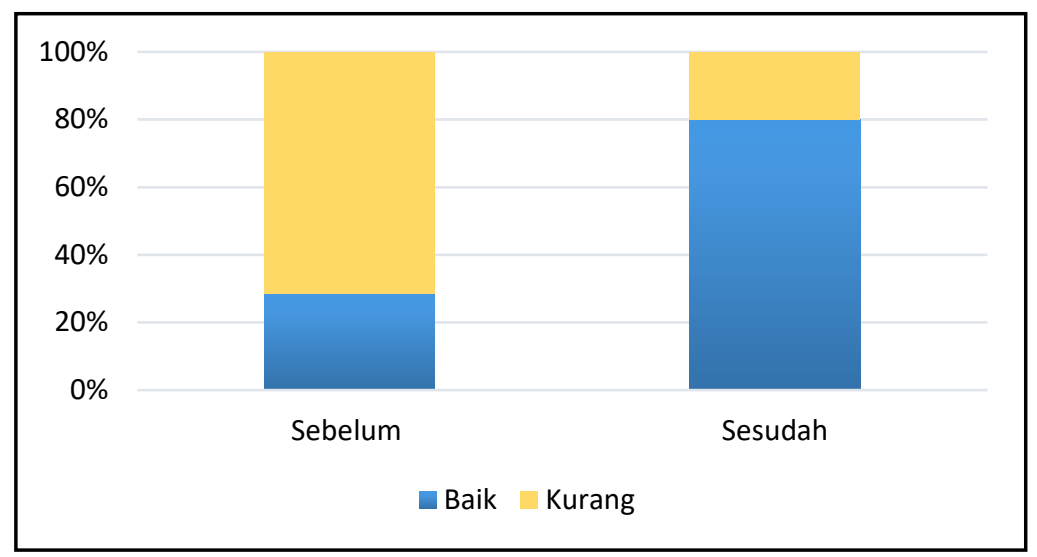

Gambar 3. Pengetahuan Peserta Sebelum dan Sesudah Sosialisasi dan Pelatihan

Dengan terlaksananya kegiatan pengabdian kepada masyarakat di wilayah Dusun Wonorejo Kecamatan Gondangrejo Kabupaten Karanganyar ini, mampu meningkatkan pengetahuan dan ketrampilan peserta yang terlihat dari antusias peserta saat diskusi, peningkatan nilai kuesioner peserta, serta dari hasil evaluasi kepada peserta dimana terdapat $20 \%$ sudah mempraktikkan langsung secara mandiri dirumah dalam pembuatan tepung tempe tempe dan digunakan dalam pengolahan produk makanan sebagai pengganti penggunaan tepung terigu.

\section{KESIMPULAN}

Pelaksanaan pendidikan kesehatan berupa sosialisasi manfaat tempe dan pelatihan pengolahan tempe menjadi tepung sebagai alternatif pengganti tepung terigu dapat meningkatkan pengetahuan, pemahaman peserta tentang nilai gizi tempe dan manfaat bagi kesehatan serta memiliki keterampilan dalam mengolah tempe menjadi tepung dan digunakan sebagai alternatif pengganti tepung terigu dalam pengolahan produk makanan sehari-hari di tingkat rumah tangga.

Dalam kegiatan selanjutnya, perlu dilakukan kegiatan sosialisasi dan pelatihan serupa dengan sasaran kelompok UKM guna meningkatkan pendapatan perekonomian suatu wilayah, dan perlu dilakukan kegiatan lanjutan yang berkaitan dengan contoh proses pengolahan produk makanan berbahan dasar tepung tempe. 


\section{DAFTAR PUSTAKA}

Astawan, M. (2013). Jangan Takut Makan Enak: Sehat Dengan Makanan Tradisional. Jilid 2. Jakarta : PT Kompas Media Nusantara.

Badan Standardisasi Nasional. (2009). Tempe. SNI No. 3144-2009. Badan Badan Standardisasi Nasional. Jakarta

Bastian, F., Ishak, E., Tawali, A. B., \& Bilang, M. (2013). Daya Terima dan Kandungan Zat Gizi Formula Tepung Tempe Dengan Penambahan Semi Refined Carrageenan dan Bubuk Kakao. Jurnal Aplikasi Teknologi Pangan, 2(1).

Elisabeth, Dian, AA., dkk. (Tanpa tahun). Respon Pengrajin Tempe Terhadap Introduksi Varietas Unggul Kedelai Untuk Produksi Tempe. Balai Penelitian Tanaman Aneka Kacang dan Umbi

FAO/WHO. (2004). Guidelines on Formulated Suplementary Food for Older Infant and Young Children. Roma:FAO/WHO

Harahap, R. H., Lubis, Z., \& Kaban, J. (2018). Komponen Flavor Volatil Tempe yang Dibungkus dengan Daun Pisang dan Plastik. Agritech, 38(2), 194-199.

Jahari AB. (2004). Status Gizi Balita di Indonesia Sebelum dan Selama Krisis, Prosidding Widyakarya Nasional Pangan dan Gizi VII. Jakarta : LIPI

Kurnia, P., \& Rahmawaty, S. (2009). Efek Fortifikasi Fe dan Zn pada Biskuit yang Diolah dari Kombinasi Tempe dan Bekatul untuk Meningkatkan Kadar Albumin Anak Balita Kurang Gizi yang Anemia (Doctoral dissertation, (ppmums).

Koeryaman, M. T., \& Ermiati, E. (2018). Adaptasi gejala perimenopause dan pemenuhan kebutuhan seksual wanita usia 50-60 tahun. MEDISAINS, 16(1), 21-30.

Meliono, I. (2007). Pengetahuan. In : MPKT Modul I, Jakarta : FEUI

Oktavia, A. N. (2012). Studi Pembuatan Tepung Formula Tempe. Skripsi). Makasar: Universitas Hasanuddin.

Permatasari, O., Muhlishoh, A., \& Ardya, H. (2020). Upaya Peningkatan Pengetahuan Tentang Peran Antioksidan Bagi Kesehatan Di Lingkungan Dusun Wonorejo Kecamatan Gondangrejo Kabupaten Karanganyar. JURNAL KREATIVITAS PENGABDIAN KEPADA MASYARAKAT (PKM), 3(2), 460-466.

Permatasari, O., Murwani, R., \& Rahfiludin, M. Z. (2018). Tempe nuggets provision improves energy adequacy and protein intake in underweight underfive children. Current Research in Nutrition and Food Science Journal, 6(1), 89-96.

Permatasari, P. K., \& Rahayuni, A. (2013). Nugget tempe dengan substitusi ikan mujair sebagai alternatif makanan sumber protein, serat, dan rendah lemak (Doctoral dissertation, Diponegoro University).

Purba, H. H., \& Maarif, M. S. (2018). Pengembangan Produk Makanan Cokelat Berbasis Preferensi Konsumen. Journal of Agroindustrial Technology, 28(1).

Pradeksa, Y., Darwanto, D. H., \& Masyhuri, M. FAKTOR-FAKTOR YANG MEMPENGARUHI IMPOR GANDUM INDONESIA. Agro Ekonomi, 25(1).

Rizqiea, N. S. (2019). Pengaruh Pemberian Booklet Asi Eksklusif Terhadap Pengetahuan Dan Keterampilan Ibu. Jurnal Ilmiah Kesehatan Media Husada, 8(1), 15-21.

Safitri, D. F., Hastuti, S., \& Widyasih, H. (2018). Pengaruh Pemberian Booklet Terhadap Peningkatan Pengetahuan, Sikap, dan Dukungan Suami Terhadap ASI Eksklusif pada Ibu Hamil di Puskesmas Ngampilan dan Puskesmas Wirobrajan (Doctoral dissertation, Poltekkes Kemenkes Yogyakarta). 